Original Research

\title{
Evaluating the Effects of Climatic Parameters on Growth and Biomass Production of Miscanthus in Climate Conditions of Southern Slovakia
}

\author{
Marián Kotrla ${ }^{1 *}$, Martin Prčík ${ }^{2}$ \\ ${ }^{1}$ Department of Regional Bioenergy, Faculty of European Studies and Regional Development, \\ Slovak University of Agriculture, Nitra, Slovak Republic \\ ${ }^{2}$ Department of Sustainable Development, Faculty of European Studies and Regional Development, \\ Slovak University of Agriculture, Nitra, Slovak Republic
}

Received: 15 June 2018

Accepted: 25 November 2018

\begin{abstract}
International trends in the development of the bioenergy sector are currently geared toward increasing the volume and quality of green energy, as well as its economic, energy and environmental profitability. For the cultivation of fast-growing energy plants, it is important to identify species and their hybrids that are able to effectively exploit the conditions that different climatic regions offer them in order to create as much biomass yield as possible. The physiological processes of plants such as energy exchange, photosynthetic $\mathrm{CO}_{2}$ assimilation, and water loss by transpiration are firmly linked to the air environment. Daily air temperatures and daily precipitation values from the Physicus meteorological station were used to evaluate climatic indicators. Then the values sum of active temperatures and hydrothermal coefficients were calculated. Growth dynamics and aboveground biomass production of Miscanthus were evaluated based on the percentage increment between measurements during the main vegetation period in the years under review. Multiple regression of dependence on growth parameters from SAT and HTC confirmed that microclimates of the site may affect plantations in particular by humidity conditions during the main vegetation period. Temperature conditions during the vegetation period do not affect growth dynamics.
\end{abstract}

Keywords: moderate climate, SAT, hydrothermal coefficient, Miscanthus, biomass production

\section{Introduction}

Although the effects of climate change across the world and regions are different, its adverse effects on socio-economic systems and landscapes are increasingly

*e-mail: marian.kotrla@uniag.sk important and require an active solution. There is a gradual change of the main features of the territory, which also changes the possibility and the method of its use, as well as the structure of the population itself. Renewable energy plays a key role in the longterm strategy of the European Commission (a secure, competitive and decarbonized energy system in 2050), as outlined in its Energy Roadmap 2050 [1]. 
The European Commission [2] outlined the areas in which efforts should be improved by 2020 in order to further increase EU renewable energy production by 2030 as well as in the coming years.

Growing energy crops for energy and non-energy purposes has great ecological importance, with a reduction of the greenhouse effect, an alternate of non-renewable energy sources and many other environmental benefits associated with more intensive use of natural resources in the environment and minimizing the cost of removing potential environmental risks. Growing energy crops respects the biological limits of a particular environment, and it is about the use the human potential of the territory, and using the energy of the environment in its natural flow. Targeted growth of energy plants has a fundamental importance today and in the future. For its successful implementation, it is essential to focus and test energy crops under different microclimatic conditions.

The most used energy plants with high environmental benefit are fast-growing trees. The species Salix spp., Popolus spp., Alnus spp. and Robinia spp. are used in the conditions of Europe and North America. Under mild climate conditions other woody plants, e.g., Eucalyptus sp. [3], Accacia sp. [4] and others are used. A promising alternative energy source is also the use of microalgal biomass [5]. Significant advances have been made in recent decades in the knowledge of the cultivation of energy grasses (Miscanthus spp., Arundo spp., Panicum spp., Sorghum spp. and Phalaris spp.) in Europe [6-9]. Research has invested considerable resources in identifying potential yields under different climatic conditions and variable cultivation management practices.

From energy grasses, Miscanthus plants are well adapted to changing environmental conditions. Miscanthus is a plant with $\mathrm{C}_{4}$ of carbon conversion type that efficiently uses solar radiation [10, 11]. Species and their hybrids grow rapidly, reach an average height of 3-4 m and form massive biomass $\left(>20\right.$ t.ha $\left.^{-1}\right)$ with high cellulose and lignin contents [12]. They use water efficiently $[13,14]$.

The aim of this paper is to evaluate the influence of the climate conditions of southern Slovakia on the dynamics of growth and production of the aboveground biomass of two miscanthus genotypes (Miscanthus $\times$ giganteus and Miscanthus sinensis (Tatai)) of energy grass. Growth and production dynamics are assessed against the sum of active temperature and hydrothermal coefficients during the main vegetation period.

\section{Material and Methods}

Experimental plantation of fast-growing energy grass is located on unused agricultural land in Kolín̆any village in the Nitra region of southwestern Slovakia (48²1'22.1'N 18¹2'23.9”E). The main soil unit is fluvial glue, which belongs to medium hard land according to the grain. From the point of view of the climatic regionalization of Slovakia, the research plantation belongs to the area of a warm, very dry and lowland-climatic region [15].

The experimental plantation of Miscanthus was established in 2010. It is one mixed plantation with two types of Miscanthus genotypes. Two types of planting were used to establish the plantation. Miscanthus $\times$ giganteus [16], where the planting material was rhizomes, and Miscanthus sinensis (Tatai), where planting material was seeded in vitro. For evaluation, 15 individuals were selected from each type of genotype. In the evaluation of growth and production characteristics, the mean values for both types of genotypes were used.

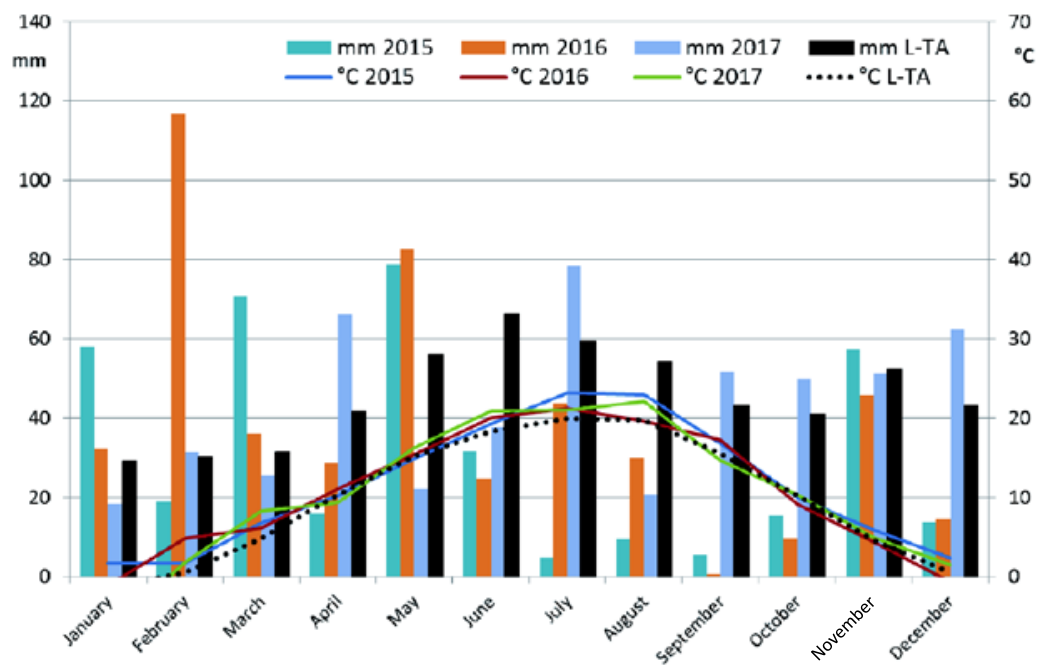

Fig. 1. Measured values of monthly air temperatures and monthly precipitation sums for years 2015-2017 at the research site and comparison with long-term average (L-TA). 
The values from the meteorological station (Fig. 1), which is located near the experimental plantation since 2015, were used to measure the climatic indicators. Daily air temperatures and daily precipitation were measured at 10-minute intervals. These indicators were needed to calculate agroclimatological indicators. The long-term average reflects the 50-year period from 1951 to 2000 from the Nitra region.

The agroclimatological indicator was calculated from the daily 2-m air temperatures for each year of the study period - the sum of active temperatures (SAT). SAT is considered to be one of the most important thermal parameters in agroclimatology in general. SAT is the sum of mean daily temperatures equal to or higher than $10^{\circ} \mathrm{C}$ [17] in the period 1 April - 31 October [18]. It is calculated as follows:

$$
\mathrm{SAT}=\sum_{01.04}^{31.10} T_{d} \text { for } T_{d} \geq 10^{\circ} \mathrm{C}
$$

...where $\mathrm{Td}$ is the daily mean air temperature.

The primary source of moisture for the Miscanthus is atmospheric precipitation. They are not optimally distributed according to the need for the moisture in the individual growth phases. The precipitation characteristics were calculated: sum of atmospheric precipitation per year and sum of atmospheric precipitation during the main vegetation period (MVP). Using the precipitation amounts and sums of temperatures $>10^{\circ} \mathrm{C}$ for the vegetative period of the year we calculated hydrothermal coefficient (HTC) by Seljaninov for each year of the period 2015-2017:

$$
\mathrm{HTC}=\frac{\mathrm{N}}{0.1 \sum T}
$$

...where $\mathrm{N}$ is the absolute precipitation in $\mathrm{mm}$ for a given month/season, and $\sum \mathrm{T}$ is the sum of the daily average temperatures of $10^{\circ} \mathrm{C}$ or above for the relevant month/ season.

The HTC is calculated only for months and periods in which the average air temperature is $10^{\circ} \mathrm{C}$ or higher. For HTC values $>1$, resp. HTC $<1$, the landscape has an abundance, resp. deficiency of moisture, with HTC $=1$ the vapour is equal to the precipitation, so the country has a balanced equilibrium [19]. The HTC provides a more detailed definition of humidity and drought climate conditions.

The dynamics of the number of shoots, their extension growth and the shoot diameters were monitored during the vegetation year (in each year of the research). The number of shoots is given in pieces and their individual increments in $\mathrm{mm}$. The plant height was determined as the distance from the soil surface to the peak of the longest shoot. The width of the tillering circle was evaluated on the basis of the direct method of measurement, for individual Miscanthus grasses, based on the area of the circle. The growth dynamics of aboveground biomass were evaluated by a destructive method during individual field measurements. The collected biomass was then dried in an oven at $105^{\circ} \mathrm{C}$ and the dry weight was expressed.

The frequency of growth analysis was performed at two-week intervals during the main vegetation period of April to October (first measurement of April 21 and last measurement of October 19). A total of 14 field measurements of selected plant species were carried out in each monitored year.

The statistical evaluation of the data was processed in STATISTICA 12 software by StatSoft. Inc. Oneway ANOVA analysis and multiple regression involves a single dependent variable (measured parameters during vegetation period) and two independent variables (SAT and HTC) were used. The result is statistically significant if $p<0.05$ or statistically highly significant if $\mathrm{p}<0.01$.

\section{Results and Discussion}

\section{Evaluation of Miscanthus Plantation Site According to Selected Climatic Parameters}

The planting of fast-growing grass Miscanthus is situated in the local climatic conditions of southwestern Slovakia. Fig. 2 shows deviations of mean values from long-term average. According to the long-term average (1951-2000), the years 2015-2017 were analyzed in terms of air temperature over the vegetation period as above average and in terms of precipitation of the values before and after the end of the main vegetation period were above average, but during the summer months (JuneAugust) the totals were below average. The amount of precipitation before the main vegetation period provided sufficient water for activating the growth of individuals.

The definition of the main vegetation period is given in Table 1. The average length of the main vegetation period is 177 days in the microclimatic conditions of southwestern Slovakia. Differences in each year depend on the average daily air temperature above $10^{\circ} \mathrm{C}$. This is the temperature at which the growth of Miscanthus shoots is activated. The authors [20] indicate the length of the vegetation period as a limiting factor for the cultivation of Miscanthus. This period is defined as the biomass start-up period beginning at an average daily temperature of $\geq 10^{\circ} \mathrm{C}$ and a total precipitation during the vegetation period $\geq 400 \mathrm{~mm}$. The beginning of growth is detected at the end of March or beginning of April. Despite the days of MVP, there were recorded days when the average daily temperature fell below $10^{\circ} \mathrm{C}$. The negative climatic event was nighttime frosts at the end of April 2016 and 2017. In 2016, on April 26, it reached a minimum temperature of $-1.45^{\circ} \mathrm{C}$ with a daily average air temperature of $7.90^{\circ} \mathrm{C}$ and on April $28-0.87^{\circ} \mathrm{C}$ (daily average $4.58^{\circ} \mathrm{C}$ ). In 2017 , on April 21, the minimum air temperature was measured at $-1.36^{\circ} \mathrm{C}$ (daily average $6.12^{\circ} \mathrm{C}$ ). These ground frosts partially damaged the shoots of the Miscanthus, as they were 
a)

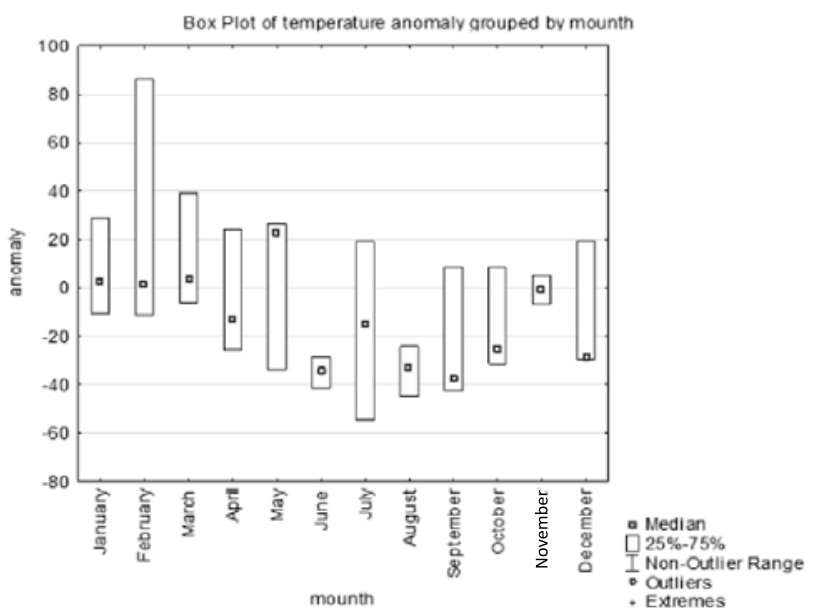

b)

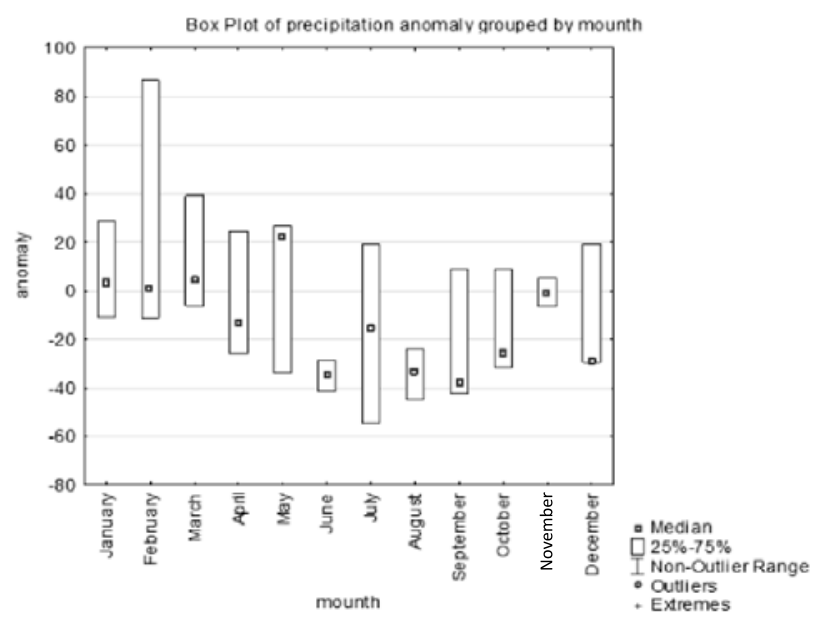

Fig. 2. Box diagram of deviations of: a) average monthly air temperatures and b) average monthly precipitation of 2015-2017 from longterm average.

already activated. The spring frosts damaged only some assimilation organs of individuals and prevented the growth of new shoots and the growth of the height of the already cast shoots.

The sum of accumulative temperatures (SAT) during the main vegetation period is one of the most basic characteristics used to evaluate the temperature relationships. When evaluating the sum of active temperatures, a higher value from long-term normal was recorded by an average of $7.7 \%$. There was a high linear correlation in SAT relative to L-TA $(r=0.7818)$.

For the analysis of the impact of temperature and precipitation in the microclimatic conditions of southwestern Slovakia on the growth and biomass production of Miscanthus, SAT and HTC were evaluated from the beginning of the growth of individuals to the end of the vegetation period at two-week intervals (Fig. 3). A total of 14 measurements were recorded during the main vegetation period in 2015-2017. High statistical significance $(\mathrm{p}=0.000001)$ was found out at SAT for the beginning to the end of the main vegetation period years of 2015 to 2017. HTC values between 2015 and 2017 are statistically not significant $(\mathrm{p}=0.088356)$. The start of MVP was determined at the end of March and early April. The end of MVP was in the first decade of October. The course of the SAT and HTC values during the 2015-2017 vegetation period is shown in Fig. 3.

\section{Analysis of Growth Dynamics and Production of Miscanthus Energy Grass}

The dynamics of growth and production of Miscanthus above-ground biomass (Fig. 4) were evaluated on the basis of the percentage increase between the measurements during the main vegetation period years 2015 and 2017. As can be seen from the graphs in Fig. 4, the greatest increase in the growth and dynamics of above-ground biomass formation was at the beginning of the vegetation period in all the years under review. The biomass dynamics formation has been evaluated since the third sampling (Fig. 4a). The formation of above-ground biomass reached the largest two-week increments in the first decade of June (more than a $100 \%$ increase). In the summer months, the additions were minimal, influenced by the growth density and microclimate. At the end of the vegetation period there was a slight decrease in biomass due to the end of the vegetation period and the gradual foliage.

The growth dynamics of shoots were influenced by intraspecific competition. More than $100 \%$ of shoot increase was in the first month of individuals' growth (Fig. 4b). Subsequently, the dynamics of the growth of new shoots slowed down and the number of shoots in the clump began to decline from the end of June. The reason for the decrease of the shoots in the clump is

Table 1. Selected climatic parameters measured and evaluated in microclimatic conditions of southwestern Slovakia (Nitra region).

\begin{tabular}{|c|c|c|c|c|c|}
\hline Year / indicator & $\mathrm{TS} \geq 10^{\circ} \mathrm{C}$ & $\mathrm{L}-\mathrm{TA} \mathrm{TS} \geq 10^{\circ} \mathrm{C}$ & $\mathrm{td} \geq 10^{\circ} \mathrm{C}$ & beginning of MVP & end of MVP \\
\hline 2015 & 3328.03 & \multirow{3}{*}{3000} & 180 & 10.4. & 10.10. \\
\cline { 1 - 4 } 2016 & 3170.12 & & 176 & 30.3. & 04.10. \\
\cline { 1 - 2 } 2017 & 3195.40 & & 176 & 20.3. & 06.10. \\
\hline
\end{tabular}

TS - sum of the temperatures; L-TA - long-term average; td - number of days; MVP - main vegetation period 


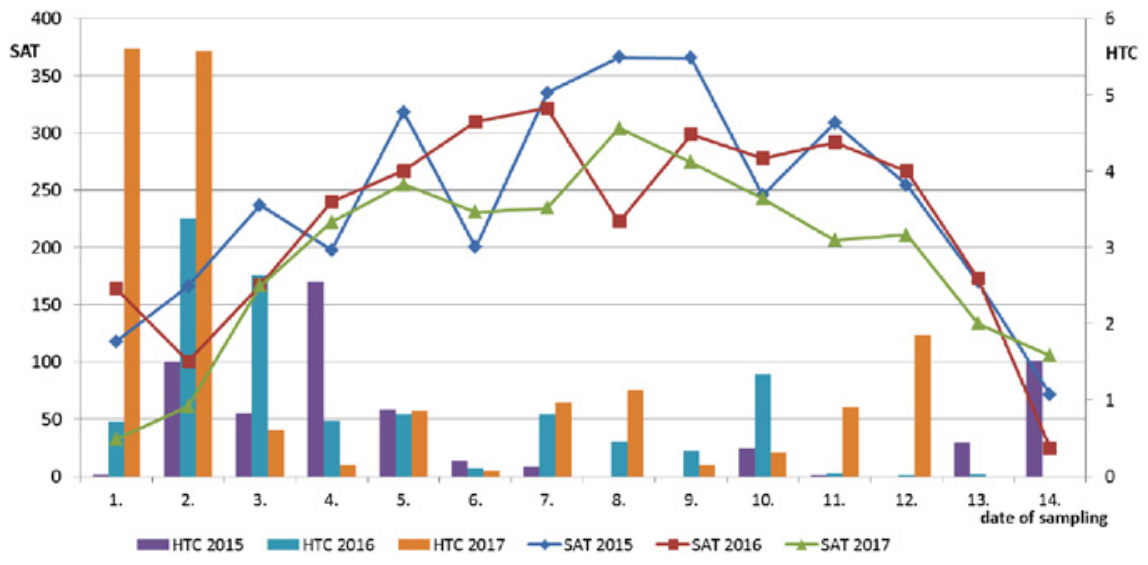

Fig. 3. SAT and HTC values for the two-week intervals of Miscanthus measurement during the main vegetation period 2015-2017 in the microclimatic conditions of southwestern Slovakia.

the competition of the shoots on the habitat conditions, especially light conditions. The decreasing number of shoots ensured the growth of the other shoots in terms of height and thickness. The growth rate of individuals peaked in the first month of the growth, when the two-week increment of height was 159.5 to $101.3 \%$ on average (Fig. 4c). In the summer months (July-August), the 2-week increase in plant height averaged only $7.9-3.3 \%$. Growth dynamics of individuals at the end of the vegetation period reached minimal two-week increases. Additionally, the shoot diameter gains

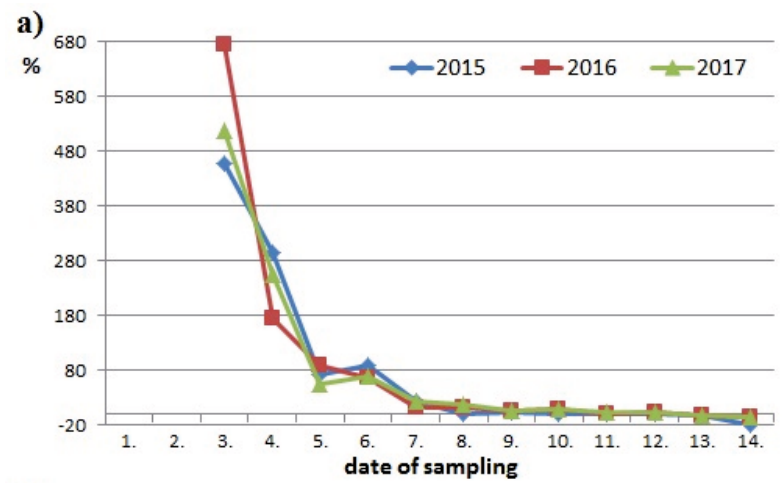

c)

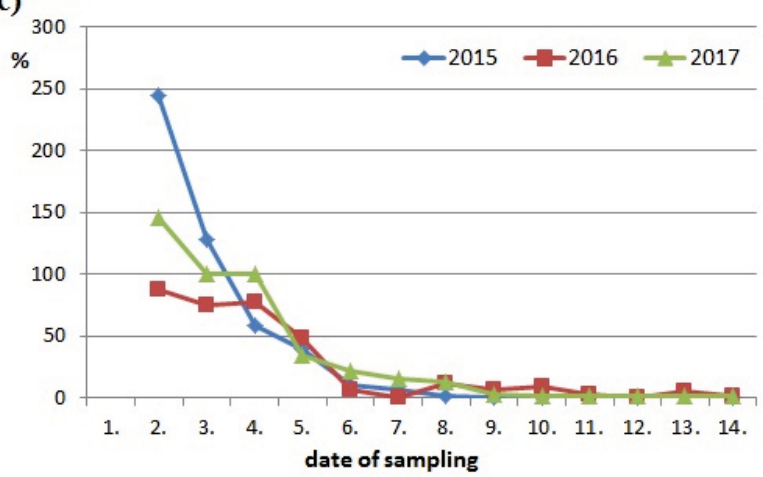

maximum in the first month (66.7 and $22.7 \%$ on average). Other increments in shoots were about $1.8 \%$ on average by the end of the vegetation period (Fig. 4d). The authors [21] published research of shoot growth in the Miscanthus sinensis population under various climatic conditions. They confirmed the influence of climatic conditions during the vegetation period on the density and height of the shoots. The seasonal changes of the shoot height and number of shoots are comparable.

Based on the periodic measurements of growth dynamics of all measured indicators, the fastest growth b)

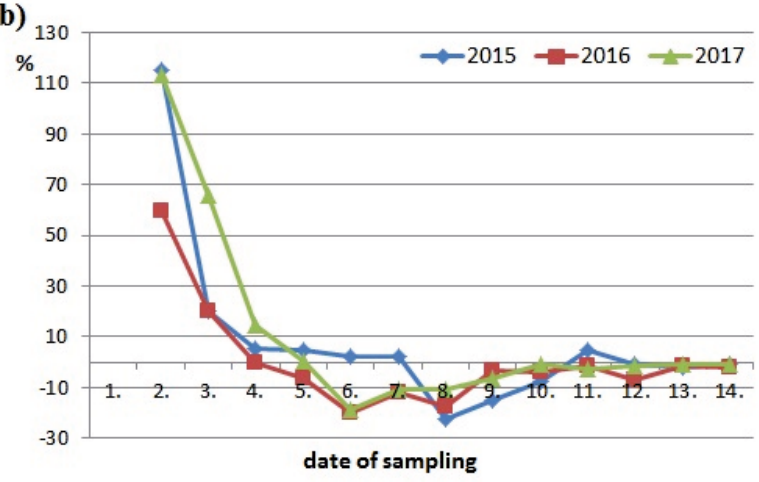

d)

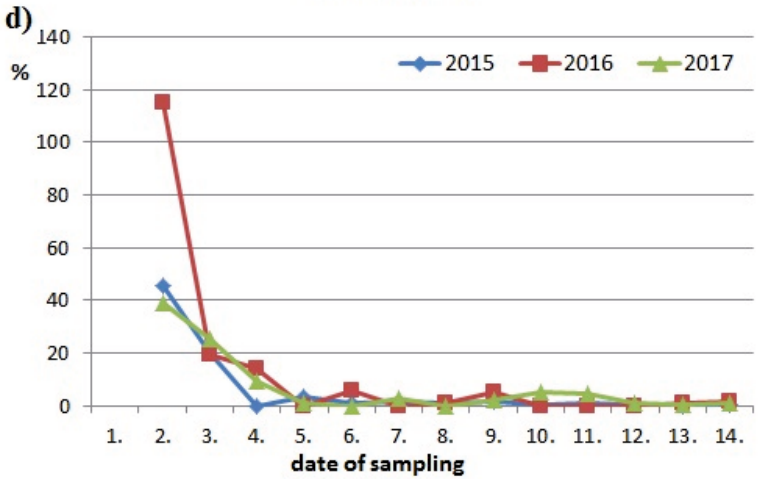

Fig. 4. Increases in measured parameters at two-week intervals during the main vegetation period of 2015-2017, expressed as a percentage: a) dynamics of biomass b) number of shoots c) plant height d) shoot diameter. 
Table 2. Multiple regression of increments of measured growth and production parameters during the main vegetation period years under review from SAT and HTC.

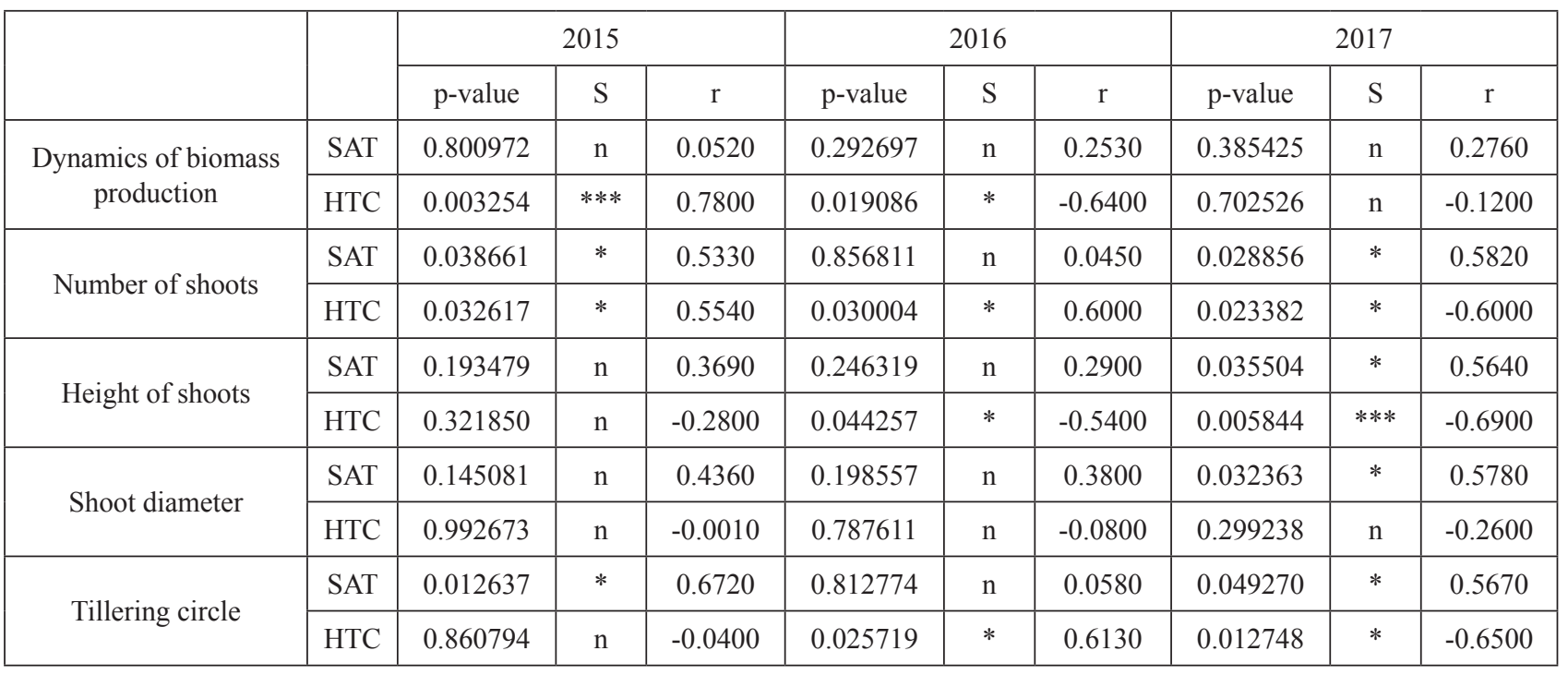

$\mathrm{S}$ - Level of significance is defined as: $\mathrm{n}$ : non-significant impact, *: significant impact in $\mathrm{P} \leq 0.05, * *: \mathrm{P} \leq 0.01$ and ***: $\mathrm{P} \leq 0.001 ; \mathrm{r}-$ Pearson's correlation coefficient; SAT - sum of accumulative temperatures; HTC - hydrothermal coefficient

and therefore the increase of the evaluated parameters are in the first month of growth (mid-April to midMay). Microclimatic parameters, adequate precipitation before growth in early spring and favorable temperature conditions (high SAT) are also beneficial. Minimum summer increments are also affected by HTC. According to HTC, for the summer months, catastrophic drought, drought and a lack of moisture were detected. An exception was only the third decade of July 2017, when there was enough rain water for the growth of individuals. The end of the main vegetation period was also characterized by dry periods in the years under review. The dry period had an impact on the small increase in the increments of the evaluated parameters.

Multiple regression of the dependence of the assessed growth parameters on SAT and HTC is shown in Table 2. Based on this, it can be concluded that the microclimates of the area can influence the growth dynamics of Miscanthus grass plantings in particular by moisture conditions during the main vegetation period. The lack of precipitation, as the only source of water for Miscanthus in a particular territory can be one of the main determinants of the growth and production of this alternative energy source. The authors [22] published research on the impact of drought on the growth of bioenergy crops grown in the Midwestern USA. They confirmed the short-term negative impact of drought during the vegetation period on Miscanthus production. The authors [23] examined the effects of drought on quality and the amount of three bioenergetics plants. They confirmed that drought during the vegetation period significantly reduces the yield of Miscanthus $\times$ giganteus biomass. Temperature conditions during the vegetation period do not affect growth dynamics. Air temperature determines the start and end of activation of growth during the vegetation period. High temperatures during the summer months affect the rapid evaporation of water and thus reduce the humidity conditions of the site. The low temperatures (frosts) in the spring period can slow growth and thus the overall production of biomass. Nevertheless, the ability of the grass to adapt its growth and biomass production to microclimatic conditions has been established. The researchers [24] evaluated the impact of soil and climatic conditions on the growth and production of Miscanthus sinensis varieties in the microclimatic conditions of northeastern Romania. The results of the research have shown the good adaptability of the studied varieties at soil and especially climatic conditions.

\section{Conclusions}

The establishment of Miscanthus plantations is also conditioned by local climatic conditions. For biomass production, the length of the main vegetation period is important. The climatic conditions of southwestern Slovakia have a positive impact on growth and biomass production. The average length of the vegetation period (177 days) enables individuals to grow the aboveground biomass over the entire vegetation period. Spring frosts were detected at the research plantation at the end of April. These had a negative impact on the resulting values in the years of their occurrence. The growth dynamics and above-ground biomass production of Miscanthus was assessed based on the percentage increase between measurements during the main vegetation period in 2015-2017. Based on periodic measurements of the growth dynamics of all measured parameters, the fastest growth and thus the increment 
of the evaluated parameters are in the first month of growth (mid-April to mid-May). The multiple regression of the dependence of the growth parameters from the SAT and HTC values confirmed that the microclimate at the Miscanthus plantation can be affected in particular by moisture conditions during the main vegetation period. The lack of precipitation can be one of the main determinants of the growth and production of this alternative energy source. Temperature conditions during growth do not affect the growth dynamics of the crop. Air temperature determines the start and end of activation of growth during the vegetation period. Nevertheless, the ability of energetic grass to adapt its growth and biomass production to microclimatic conditions was recognized.

\section{Acknowledgements}

This work was supported by grant agency FESRD as project No. 3/2017.

\section{Conflict of Interest}

The authors declare no conflict of interest.

\section{References}

1. $\operatorname{COM}(2011) 0885$ Energy Roadmap 2050.

2. $\operatorname{COM}(2012) 0271$ Renewable Energy: a major player in the European energy market.

3. BARREIRO S., TOMÉ M. Analysis of the impact of the use of Eucalyptus biomass for energy on wood availability for Eucalyptus forest in Portugal: a Simulation study. Ecology and Society, 17 (2), 2012.

4. ZHANG H., GUAN D., SONG M. Biomass and carbon storage of Eucalyptus and Acacia plantations in the Pearl River Delta, South China. Forest Ecology and Management, 277, 90, 2012.

5. GŁOWACKA N., GADUŠ J., SLOBODNÍK J. Anaerobic digestion of microalgal biomass Acutodesmus dimorphus (Turpin) P. Tsarenko as a substrate for biogas production. Polish Journal of Environmental Studies, 27 (4), 1497, 2018.

6. MATYKA M., KUŚ J. Influence of soil quality for yielding and biometric features of Miscanthus $\times$ giganteus. Polish Journal of Environmental Studies, 25 (1), 213, 2016.

7. CORNO L., PILU R., ADANI F. Arundo donax L.: a non-food crop for bioenergy and bio-compound production. Biotechnology advances, 32 (8), 1535, 2014.

8. ZEGADA-LIZARAZU W., PARRISH D., BERTI M., MONTI A. Dedicated crops for advanced biofuels: Consistent and diverging agronomic points of view between the USA and the EU-27. Biofuels, Bioproducts and Biorefining, 7 (6), 715, 2013.

9. COSENTINO S.L., SCORDIA D., SANZONE E., TESTA G., COPANI V. Response of giant reed (Arundo donax L.) to nitrogen fertilization and soil water availability in semi-arid Mediterranean environment. European journal of agronomy, 60, 22, 2014.
10. GAUDER M., GRAEFF-HÖNNINGER S., LEWANDOWSKI I., CLAUPEIN, W. Long-term yield and performance of 15 different Miscanthus genotypes in southwest Germany. Annals of Applied Biology, 160 (2), 126, 2012.

11. HEATON E.A., DOHLEMAN F.G., MIGUEZ A.F., JUVIK J.A., LOZOVAYA V., WIDHOLM J., ZABATINA O.A., MCISAAC G.F., DAVID M.B., VOIGT T.B., BOERSMA N.N., LONG S.P. Miscanthus: a promising biomass crop. Advances in Botanical Research, 56, 75, 2010.

12. ANDERSON E., ARUNDALE R., MAUGHAN M., OLADEINDE A., WYCISLO A., VOIGT T. Growth and agronomy of Miscanthus $\times$ giganteus for biomass production. Biofuels, 2 (2), 167, 2011.

13. BEALE C.V., MORISON J.I.L., LONG S.P. Water use efficiency of $\mathrm{C}_{4}$ perennial grasses in a temperate climate. Agricultural and Forest Meteorology, 96, 103, 1999.

14. MAUGHAN M., BOLLERO G., LEE D.K., DARMODY R., BONOS S., CORTESE L., MURPHY J., GAUSSOIN R., SOUSEK M., WILLIAMS D., WILLIAMS L., MIGUEZ F., VOIGT T. Miscanthus $\times$ giganteus productivity: the effects of management in different environments. Gcb Bioenergy, 4 (3), 253, 2012.

15. KOTRLA M., MANDALOVÁ K., PRČÍK M. Regional disparities in Slovakia and the Czech Republic in the context of sustainable growing of energy plants. European Journal of Sustainable Development, 6 (2), 165, 2017.

16. GREEF J.M., DEUTER M. Syntaxonomy of Miscanthus $\times$ giganteus GREEF et DEU. Angewandte Botanik, 67, 87, 1993.

17. LISEK J. Climatic factors affecting development and yielding of grapevine in central Poland. Journal of Fruit and Ornamental Plant Research, 286, 285, 2008.

18. JONES G.V., DAVIS R.E. Using a synoptic climatological approach to understand climate-viticulture relationships. International Journal of Climatology, 20 (8), 813, 2000.

19. SELJANINOV G.T. Agroclimatic Map of the World. Hydrometeoizdat Publishing House, Leningrad, 1966.

20. XUE S., LEWANDOWSKI I., WANG X., YI, Z. Assessment of the production potentials of Miscanthus on marginal land in China. Renewable and Sustainable Energy Reviews, 54, 932, 2016.

21. KOBAYASHI K., YOKOI Y. Shoot density of Miscanthus sinensis populations in different habitats and their maintenance mechanisms in relation to shoot growth. Journal of plant research, 130 (1), 143, 2017.

22. JOO E., HUSSAIN M.Z., ZERI M., MASTERS M.D., MILLER J.N., GOMEZ-CASANOVAS N., DELUCIA E.H., BERNACCHI C.J. The influence of drought and heat stress on long-term carbon fluxes of bioenergy crops grown in the Midwestern USA. Plant, cell \& environment, 39 (9), 1928, 2016.

23. EMERSON R., HOOVER A., RAY A., LACEY J., CORTEZ M., PAYNE C., KARLEN D., BIRELL S., LAIRD D., KALLENBACH R., EGENOLF J., SOUSEK M., VOIGT T. Drought effects on composition and yield for corn stover, mixed grasses, and Miscanthus as bioenergy feedstocks. Biofuels, 5 (3), 275, 2014.

24. CHELARIU E.L., DRAGHIA L., ASĂNICĂ A., AVARVAREI B.V. Behaviour of Miscanthus sinensis varieties in pedo-climatic conditions from North-East of Romania. Romanian Biotechnological Letters, 20 (2), 10295, 2015. 
